\title{
気泡を含む液体金属中における熱衝撃に伴う圧力波の伝播*
}

\author{
沖田 浩 平*1, 高木 周*1, 松本 洋一郎*1
}

\section{Propagation of Pressure Waves, Caused by a Thermal Shock, in Liquid Metals Containing Gas Bubbles}

\author{
Kohei OKITA*2, Shu TAKAGI and Yoichiro MATSUMOTO \\ ${ }^{* 2}$ Department of Mechanical Engineering, The University of Tokyo, \\ 7-3-1 Hongo, Bunkyo-ku, Tokyo, 113-8656 Japan
}

\begin{abstract}
Propagation of pressure waves caused by a thermal shock in liquid metals containing gas bubbles is performed by a numerical simulation. The present study examined the influences of bubble radius and void fraction on the absorption of thermal expansion of liquid metals and attenuation of pressure waves. As the result of the calculation, since the large bubbles have a smaller natural frequency than small bubbles, the peak pressure at the heated region increases with increasing bubble radius. Contrary, the peak of propagated pressure wave to the wall decreases. But, when the bubble radii are around $500 \mu \mathrm{m}$, the pressure wave propagates through the mixture not with the sonic speed of the mixture but with that of liquid mercury. And the peak of such pressure wave becomes higher than that of the pressure waves which propagate with sonic speed of mixture. On the other hand, decreasing the void fraction makes behavior of bubbles nonlinear and a collapse of bubble produces a high pressure wave. However, the calculation shows that the method of introducing micro gas bubbles into liquid metals is effective to prevent cavitation erosion on the wall.
\end{abstract}

Key Words : Cavitation, Bubble Dynamics, Thermal Shock, Liquid Metals, Numerical Analysis

\section{1.}

近年, 核破砕源や次世代原子炬への液体金属の使用 が検討されており, その一例として中性子線源の開発 が進められている(1)(2). しかし, 液体金属への陽子パル ス照射による核破碎反応の瞬時発熱に伴って液体金属 が熱膨張し，それによって誘起された圧力波による構 造体の損㑥が重要な問題となっており, 損伤メカニズ ムの解明と防御策の確立が望まれている. 損倠メカニ

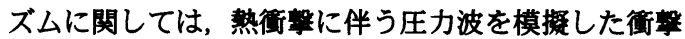
負荷実験において固体材料表面に形成されたサブミク ロンの損傷が確認されており, 固液界面に生じるキャ ビテーション気泡の崩壤によって形成されると考えら れている(3).このようなキャビテーションによる損賃 を抑制するために, マイクロバブル発生法 ${ }^{(4)}$ を応用し て, 液体金属中に微小気泡を混入する方法が提案され ている(5).これは, 微小気泡を混入することで, 液体 金属の熱膨張に伴う圧力上昇を気泡の収縮によって緩 和し，さらに圧力波を伝播過程において波の分散およ び熱散逸により減衰させるものである. 本研究の目的

* 原稿受付 2005 年 7 月 20 日

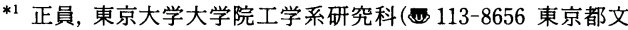
京区本郷 7-3-1).

E-mail : okita@ fel.t.u-tokyo.ac.jp
は，数值解析を用いて，微小気泡混入による圧力波低 減の効果を評価すること，および気泡径や気泡含有率 （ボイド率）といったパラメータの影䇾を明らかにす ることである.

気泡を含む液体中における圧力波の伝播に関する研 究は, Carstensen $5^{(6)}$ の多重散乱理論による解析をは じめとして, van Wijngaarden ${ }^{(7)}$ にる現象論に基づい た支配方程式系の提案から，多くの研究者らによって 行われている(8)(9)(10)(11)(12)(13). それらによれば, 気泡 を含む液体中を伝播する衐撃波は，有限の幅を持った 立ち上がりとそれに続く緩和振動領域からなっており， このような特徵が気泡の体積運動に大いに関係してい ること, とりわけ緩和掁動領域では気液界面を通して の熱伝達による気泡体積振動の熱減衰効果が重要であ ることなどがわかっている. Kameda $5^{(13)}$ は，非常に 良く制御された実験，つまり，均一な球形気泡が液体中 に低ボイド率で一様に分布しているような条件で，実 䀦的に観察される圧力波の伝播挙動を数値計算によっ て妥当に再現できることを示している. Commander \& Prosperetti ${ }^{(10)}$ は，圧力波の伝播速度および隇衰率と圧 力周波数の関係を線形解析により導出し，理論解析の 結果が線形振動する気泡に関する実験とよく一致する 


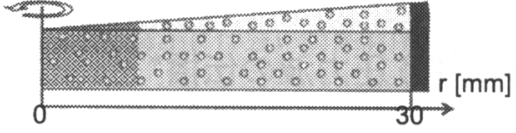

Fig. 1 Bubbly liquid metal in a cylinder

ことを示している. 本研究では, キャビテーションエ ロージョンの抑制という視点から, 気泡混入による液 体金属中の熱衝撃に伴う圧力波の緩和・減衰効果に注 目する. そのため, 気泡の体積運動に関して線形領域 だけでなく非線形領域においても，数值計算によって 圧力波の緩和・減衰に関する知見を得る。

\section{2. 基 礎方程 式}

図 1 に示すように, 円筒容器の中に微小気泡が一 様に分布した液体金属における圧力波伝播現象を考え る.はじめに，核破砕反応によって生じる瞬時発熱を 模擬した熱を円筒中心部に与える。この熱源によって 液体金属が熱膨張し，圧力上昇が生じる。そして，圧 力波が気液混相流中を円筒中心部から円筒壁に向かっ て伝播する.このような物理現象を再現するために, Kameda \& Matsumoto ${ }^{(12)}$ の基礎方程式群に加えて, 液 相のエネルギー保存式および状態方程式を考慮し，以 下に示すような基礎方程式を用いた。

2.1 気泡流 ボイド率が小さく $f_{G} \ll 1$, 気相の 密度が液相の密度に比べて無視できる場合 $\rho_{G} \ll \rho_{L}$, 一次元円筒座標系において気泡流に対する質量および 運動量保存式は液相の体積率を $f_{L}$, 速度を $u_{L}$ として,

$$
f_{L} \frac{D_{L} \rho_{L}}{D t}+\rho_{L} \frac{D_{L} f_{L}}{D t}+f_{L} \rho_{L} \frac{1}{r} \frac{\partial r u_{L}}{\partial r}=0
$$

および

$$
f_{L} \rho_{L} \frac{D_{L} u_{L}}{D t}=-\frac{\partial p}{\partial r}+\frac{\partial}{\partial r}\left\{\frac{4}{3} \mu_{e}\left(\frac{1}{r} \frac{\partial r u_{L}}{\partial r}\right)\right\}
$$

と表される. ただし， $D_{L} / D t \equiv \partial / \partial t+u_{L} \partial / \partial r$ である. ここで, $\mu_{e}$ は実効粘性であり, 液体中における気泡のサ スペンジョン効果を考慮して, $\mu_{e}=\left(1+2.5 f_{G}\right) \mu_{L}{ }^{(14)}\left(\mu_{L}\right.$ は液相の粘性係数) を用いた.

さらに，本研究では熱衝撃による圧力上昇を再現す るために液体水銀に対する状態方程式 (付録 A 参照) と次の液相に対するエネルギー保存式を用いた.

$$
f_{L} \rho_{L} C_{p L} \frac{D_{L} T_{L}}{D t}=f_{L} \beta_{L} T_{L} \frac{D_{L} p}{D t}+\frac{1}{r} \frac{\partial}{\partial r}\left(r f_{L} \lambda_{L} \frac{\partial T_{L}}{\partial r}\right)+Q
$$

ただし， $C_{p L}$ は等圧比熱， $\beta_{L}$ は等圧膨張係数， $\lambda_{L}$ は熱 伝導率である.また， $Q$ は核破砕による発熱を表して おり，粘性散逸による発熱は無視した。式 (3)におい て, ボイド率が小さく, 液相の熱容量が気相のそれに 比べて非常に大きいため, 気相の熱容量を無視した.
気泡の体積運動については, 気泡半径を $R$ として 球形を仮定して液相の圧縮性を考慮した Keller の式 (15)(16)を用いた。

$$
\begin{aligned}
& {\left[1-\frac{1}{c_{s L}} \frac{d R}{d t}\right] R \frac{d^{2} R}{d t^{2}}+\frac{3}{2}\left[1-\frac{1}{3 c_{s L}} \frac{d R}{d t}\right]\left(\frac{d R}{d t}\right)^{2}} \\
& =\frac{1}{\rho_{L}}\left[1+\frac{1}{c_{s L}} \frac{d R}{d t}+\frac{1}{c_{s L}} R \frac{d}{d t}\right]\left(p_{g w}-\frac{2 S_{L}}{R}-\frac{4 \mu_{L}}{R} \frac{d R}{d t}-p\right)
\end{aligned}
$$

ただし， $c_{s L}$ および $S_{L}$ はそれぞれ液相の音速および表 面張力係数であり, $p_{g w}$ は気泡壁における気相の圧力 $\left.p_{g}\right|_{r=R}$ である.

本研究では, 個々の気泡はラグランジュ的に取り扱 われ，気泡の合体および分裂は考えない. よって, $k$ 番の気泡が担う数密度 $n_{B k}$ を一定として, 液相体積率 は次のように求めた。

$$
f_{L}=1-\frac{1}{V_{\text {cell }}} \sum_{k \in V_{\text {aff }}} \Phi\left(x-x_{B k}\right) \frac{4}{3} \pi n_{B k} R_{k}^{3},
$$

ここで, $\Phi$ は次式で定義された近似デル夕関数である.

$$
\Phi(x) \equiv\left\{\begin{array}{cc}
\frac{1}{4}\left[\cos \left(\frac{\pi x}{2 \Delta x}\right)+1\right] & \text { for }|x| \leq 2 \Delta x \\
0 & \text { for }|x|>2 \Delta x
\end{array}\right.
$$

また, 気泡と周囲流体の相対速度が圧力波形に与える 影響はほぼ無視できるため ${ }^{(12)}$, 相対速度がないと仮定 して，気泡の位置を次のように求めた。

$$
u_{B}=\left.u_{L}\right|_{x=x_{B}}, \quad x_{B}(t)=\int_{0}^{t} u_{B} d \tau
$$

2.2 気泡内部気泡流中の圧力波の伝播過程に おいては気泡振動の熱減衰効果が重要である.よって, 気泡内部気体の質量, 運動量およびエネルギーの保存 を計算することで, 気液界面を通しての熱伝達を考虑 した.ただし, 気泡内部気体は一成分の不凝縮気体の みからなり, 気液界面を通しての蒸発, 凝縮および溶 解などの物質移動はないものとした。

気泡壁の移動を考慮した一次元極座標系 $r=$ $R(t) \sqrt{y}(0 \leq y \leq 1)$ を考えるとき, 個々の気泡の内部 における気相に対する質量, 運動量およびエネルギー 保存式はそれぞれ，

$$
\begin{gathered}
\frac{1}{\rho_{g}} \frac{D_{g} \rho_{g}}{D t}+\frac{1}{R^{2} y} \frac{2 \sqrt{y}}{R} \frac{\partial R^{2} y u_{g}}{\partial y}=0, \\
\frac{D_{g} u_{g}}{D t}=-\frac{1}{\rho_{g}} \frac{2 \sqrt{y}}{R} \frac{\partial p_{g}}{\partial y}
\end{gathered}
$$

および

$$
\rho_{g} C_{p g} \frac{D_{g} T_{g}}{D t}=\beta_{g} T_{g} \frac{D_{g} p_{g}}{D t}+\frac{1}{R^{2} y} \frac{2 \sqrt{y}}{R} \frac{\partial}{\partial y}\left(R^{2} y \lambda_{g} \frac{2 \sqrt{y}}{R} \frac{\partial T_{g}}{\partial y}\right)
$$


となる.ただし,$D_{g} / D t \equiv \partial / \partial t+\left\{\left(u_{g}-\right.\right.$ $\dot{R} \sqrt{y}) 2 \sqrt{y} / R\} \partial / \partial y$ である.また，これらの方 程式系を閉じるために，理想気体の状態方程式 $p_{g}=\rho_{g} \Re T_{g}$ を用いた.

\section{3 境界条件}

2.3.1 気泡流 円简容器中心では円筒対称, 円筒 壁面では断熟壁を仮定するとき，境界条件はそれぞれ において次のようになる.

$$
\frac{\partial p}{\partial r}=0, \quad u_{L}=0, \quad \frac{\partial T_{L}}{\partial r}=0
$$

2.3.2 気泡内部

気泡中心では, 球対称の仮定か

ら，境界条件は

$$
\left.\frac{\partial p_{g}}{\partial y}\right|_{y=0}=0,\left.\quad u_{g}\right|_{y=0}=0,\left.\quad \frac{\partial T_{g}}{\partial y}\right|_{y=0}=0
$$

となる. 一方, 気泡壁では, 気泡壁の速度と加速度が 式 (4) から求められるものと一致しなければならない. また, 気泡壁の液相側には温度分布がないと仮定して, 気泡壁の温度を周囲流体の温度と等しいとした。

$$
\left.\frac{\partial p_{g}}{\partial y}\right|_{y=1}=-\rho_{g} \frac{d^{2} R}{d t^{2}},\left.\quad u_{g}\right|_{y=1}=\frac{d R}{d t},\left.\quad T_{g}\right|_{y=1}=T_{L}
$$

\section{3. 数值町算法と計算条件}

エネルギー保存式から, 密度を圧力と温度の関数と して, 次のように表される.

$$
\frac{D \rho}{D t}=\frac{1}{c_{s}^{2}} \frac{D p}{D t}-\frac{\beta}{C_{p}}\{\nabla \cdot(\lambda \nabla T)+Q\}
$$

これより，質量保存式における密度の物質微分項を消 去して離散化し，圧力勾配項を陰的に離散化した運動 量保存式を用いて圧力に関する差分方程式が導出され， HSMAC 法に準じた手法の適用が可能となる.

連続相に対する空間および時間の離散化には，それ ぞれ 2 次精度中心差分および 1 次精度オイラー陽的積 分を用いた. また, 移流項の離散式における整合性 ${ }^{(17)}$ を保つために, 圧力, 速度および温度の移流項も中心 差分で近似するが，TVD 条件が满足されない場合に は 1 次精度の風上差分を用いた. とりわけ, 連続相の 体積率の移流項については, $f_{L}+f_{G}=1$ の関係から，

$$
\frac{D_{L} f_{L}}{D t}+\frac{D_{G} f_{G}}{D t}=\left(u_{L}-u_{G}\right) \frac{\partial f_{G}}{\partial x}
$$

より, $u_{L}=u_{G}$ の場合には右辺がゼロになることから， 連経相の体㮴率に関する移流項を離散相から求めるこ とで移流における両相の不一致を防いだ ${ }^{(18)}$.

気泡位置における流体の特性は線形補間により求め, 気泡の体積運動における時間積分は 2 次精度の陽的差 分である. 本研究では, 熱衝撃に伴う温度上昇が液体

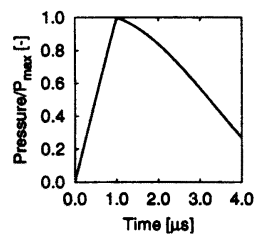

(a) Single phase

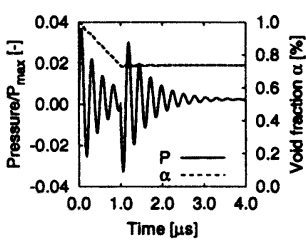

(c) $R_{0}=10 \mu m, \alpha_{0}=1 \%$

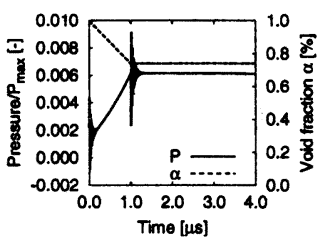

(b) $R_{0}=1 \mu m, \alpha_{0}=1 \%$

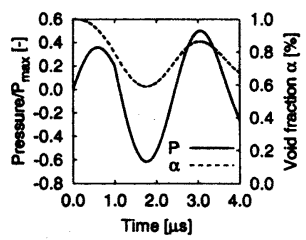

(d) $R_{0}=100 \mu m, \alpha_{0}=1 \%$
Fig. 2 Time evolution of the pressure and void fraction at the center of cylinder for various bubble radii (the pressure divided by the peak pressure in the case of single phase, $P_{\max }=72.1 \mathrm{MPa}$ )

水銀の特性に大いに影管を与えるため, この特性を温 度の関数として与えた ${ }^{(19)}$. また, ヘリウムおよびアル コンの温度伝導率には Sutherland の式 (付録 B 参照) を用いた。

計算格子については，円筒領域を 200, 個々の気泡 内部を 20 格子点で分割した.これらは，2 倍の格子 点を用いた計算と壁面圧力の最大値を比較して数\%の 誤差であり, 後述の議論を進めるにあたり妥当な精度 であることを確認している. また，計算進行時の時間 刻みは計算が破綻しないように自動的に決定した.

本計算では, $1 \mu s$ 程度の陽子パルス照射 ${ }^{(1)(2)}$ による 核破砕反応の発熱を模擬した熱源として，時間的に $1 \mu \mathrm{s}$ の矩形パルスで空間的に標準分散 $\sigma=5 \mathrm{~mm}$ の カウス分布 $Q(r)=Q_{\max } \exp \left(-r^{2} / 2 \sigma^{2}\right)$ で円筒中心部 に与えた. また, 単相状態において熱膨張によって 数十 $M P a$ オーダの圧力上昇をもたらす熱源として $Q_{\max }=26.7 \times 10^{12} \mathrm{~W} / \mathrm{m}^{3}$ を与えた.

\section{4. 郭算結果と考裋}

$4 \cdot 1$ 熟入力部の圧力变動 熱膨張に伴う圧力上 昇の緩和に対する気泡の大きさの影䇺について調べた. 図 2 に, 初期ボイド率 $\alpha_{0}=1 \%$ における円筒容器中 心軸上の圧力およびボイド率の時間変化を単相および $R_{0}=1,10,100 \mu m$ とさまざまな大きさの気泡を含む場 合について比較して示す. 単相の条件では，一定な熱 入力による熱膨張により, 圧力が $1 \mu s$ まで直線的に上 昇し, その後圧力波の伝播により降下する. 一方, 気 泡を含む場合には, 圧力上昇の最大値が単相の結果に 比べて非常に減少しており, 気泡半径が $R_{0}=1 \mu m$ の 
結果においては, 最大圧力が $1 \%$ 以下にまで小さくなっ ていることがわかる. また, 気泡半径の違いによって 圧力振動の様子が大きく異なっており， $R_{0}=100 \mu m$ の結果ではボイド率も大きく振動している. それに対 して, $R_{0}=1,10 \mu m$ ではほほ液体水銀の熱膨張に伴う ボイド率の変化を示している.

角周波数 $\omega$ の微小圧力振動に対する気泡流の複素 音速は次式のように近似される(10).

$$
\frac{1}{c_{m}^{2}}=\frac{1}{c_{s L}^{2}}+\frac{3 \alpha_{0}}{R_{0}^{2}\left(\omega_{0}^{2}-\omega^{2}+2 i b \omega\right)}
$$

ここで， $\omega_{0}$ は気泡の体積運動の固有角周波数であり， $b$ は粘性，熱および圧縮性による減衰係数である。こ れから, 気泡を含む液体における密度変化による圧力 変化が次のようになる.

$$
\frac{\partial p}{\partial \rho}=c_{m}^{2}=\frac{\omega_{0}^{2}-\omega^{2}+2 i b \omega}{\omega_{0}^{2}+3 \alpha_{0} \frac{c_{s s}^{2}}{R_{0}^{2}}-\omega^{2}+2 i b \omega} c_{s L}^{2}
$$

ここで, 気泡流の固有角周波数 $\omega_{m 0}$ を次式で定義する.

$$
\omega_{m 0}^{2} \equiv \omega_{0}^{2}+3 \alpha_{0} \frac{c_{s L}^{2}}{R_{0}^{2}}
$$

水に比べて約 13 倍大きい密度のために, 液体水銀中 の気泡は体積振動における周囲流体の慣性の影響で気 泡の固有角周波数が小さくなるが, 式(18)の右辺第 2 項が第 1 項に比べて大きくなるようなボイド率では, 液体水銀と水の音速がほぼ等しいために気泡流の固有 角周波数が液体水銀と水で同じになることがわかる.

図 3 に, 気泡半径に対する気泡の固有周波数 $f_{0}=$ $\omega_{0} /(2 \pi)$ および気泡流の固有周波数 $f_{m 0}=\omega_{m 0} /(2 \pi)$ (初 期ボイド率 $\alpha_{0}=1 \%$ の場合)を示す. 図より, 気泡が小 さくなるほど気泡および気泡流の固有周波数が高くな り, ボイド率が $1 \%$ の気泡流の固有周波数は気泡のそ れに比べて一杵以上高くなる. また, $R_{0}=1,10,100 \mu \mathrm{m}$ に対して周期 $T_{m 0}\left(=2 \pi / \omega_{m 0}\right) \simeq 0.025,0.25,2.5 \mu \mathrm{s}$ とな り,これらの周期は図 2 における圧力振動の周期にほ ぼ等しいことがわかる.

微小振動に対して，系に線形性が仮定できるとする と式(17)が熱入力に伴う密度変化による圧力変化の伝 達関数を表していると考えられる. 図4(a)にこの伝達 関数の複素フーリエ係数を示す. その特性は, 気泡流 の固有周波数 $f_{m 0}$ よりも高い周波数成分に対しては液 相の音速となるために，熱膨張に伴う圧力上昇に対す る気泡収縮による緩和効果がないが, $f_{m 0}$ より低い周 波数成分に対しては緩和効果が大きい。一方，時間的 に $1 \mu s$ の矩形パルスで表現された熱入力をフーリエ変 換すると，図 4(b) のように波数成分が $1 M H z$ より高

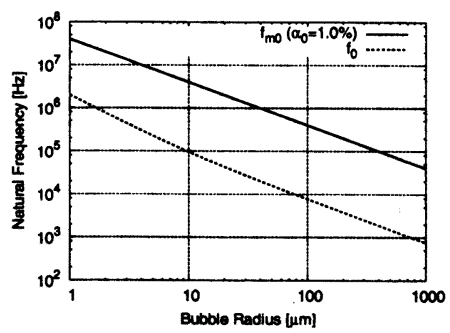

Fig. 3 Natural frequency as function of bubble radii for the single bubble and bubbly liquid $\left(\alpha_{0}=\right.$ $1 \%)$

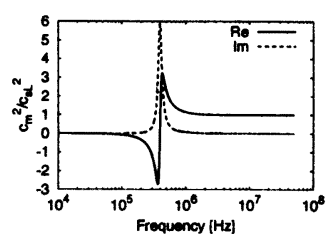

(a) Transfer function $\left(R_{0}=100 \mu m, \alpha=1.0 \%\right)$

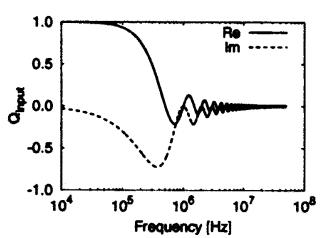

(b) Heat input
Fig. 4 Complex Fourier coefficient

くなると急激に小さくなる特徵がある.つまり,この 周波数よりも気泡流の固有周波数が高い場合には, 熱 膨張による圧力上昇が楥和されるが, 低い場合には気 泡流の固有周波数より高い成分が減衰されず, とりわ け固有周波数の圧力振動が励起されるために圧力上昇 が緩和されない.したがって, 気泡収綰による圧力上 昇の緩和に対する気泡半径およびボイド率の影篅が, 気泡流の固有周波数之熱入力の周波数特性に依存して いることがわかる.

4.2 压力波の伝眾凧程 $1 \mu \mathrm{s}$ の熱入力に対して, 気泡流の固有周波数が低い条件 $\left(R_{0}=200 \mu m, \alpha_{0}=\right.$ 1\%）における圧力波の伝播過程として, 圧力分布の時 間変化を図 5(a), および (a)における $t=0 \sim 80 \mu \mathrm{s}$ の 部分を拡大したものを(b)に示す. ただし，この計算 だけは， 2 種類の圧力波の伝播過程が明確な条件 (熟 入力の空間分布 $\sigma=1 \mathrm{~mm})$ で行った.

図 5(a)より，圧力波が中心から壁に向かって約 $30 \mathrm{~mm} / 1250 \mu \mathrm{s}=24 \mathrm{~m} / \mathrm{s}$ の速度で伝播していることが わかる. この伝播速度は式(16)で $\omega=0$ のときの音速, つまり, 気液二相流の等温平得音速 $c_{m 0}=27.6 \mathrm{~m} / \mathrm{s}$ にほ ぼ等しい. 一方, 図 5(b)より, 圧力が振動を始める点 が中心から壁に向かっておよそ $30 \mathrm{~mm} / 20 \mu \mathrm{s}=1500 \mathrm{~m} / \mathrm{s}$ と液体水銀の音速で伝播していること，また，その圧 力の振動周期が $5 \mu \mathrm{s}$ 之気泡流の固有周波数から求まる ものに等しいことがわかる.つまり，図4で見たよう に, 熱入力において $f_{m 0}$ より高い周波数成分が液体水 


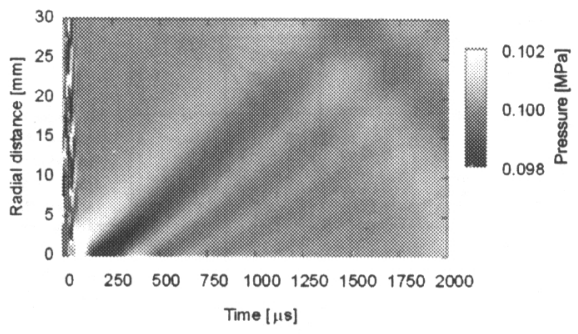

(a) Pressure propagation at sound speed of mixture

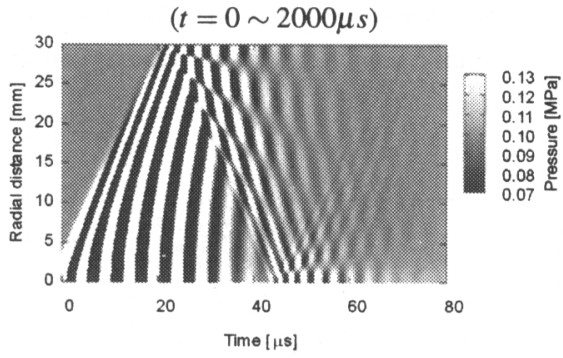

(b) Pressure propatation at sound speed of liquid mercury $(t=0 \sim 80 \mu s)$

Fig. 5 Two types of pressure propagation; time evolution of the pressure distribution under the condition of the heat input with $\sigma=1 \mathrm{~mm}$ in space $\left(R_{0}=200 \mu m, \alpha_{0}=1 \%\right)$

銀の音速で伝播している.このように, 気泡流中を伝 播する波の周波数によって, 液相の音速で伝播する波 と気液二相流の平衡音速で伝播する波に分かれること は線形解析 ${ }^{(10)}$ の結果と一致している.

4.3 圧力上昇の緩和と圧力波の減衰 熱膨張に 伴う圧力上昇の緩和および圧力波の伝播過程におけ る減衰に対するボイド率と気泡半径の両方の影響に ついて調べた. 図 6 および図 7 はそれぞれ円筒の中 心および壁面における最大圧力と気泡半径の関係を さまざまなボイド率に対して示している，ただし，中 心部圧力の最大値において, 壁からの反射波は考えて いない. 図6より, 気泡半径が小さくなるにつれて, $\alpha_{0}=0.3 \sim 1 \%$ に対する中心の最大圧力が気泡の固有周 波数の上昇に伴い徐々に小さくなるが, $R_{0}=1 \mu m$ 付近 で極小值をとって大きくなっている．液体水銀は金属 結合のために表面張力係数が $S_{H g}=490 \times 10^{-3} \mathrm{~N} / \mathrm{m}$ と 水の $S_{\mathrm{H}_{2} \mathrm{O}}=72.5 \times 10^{-3} \mathrm{~N} / \mathrm{m}$ に比べて大きく, 初期半 径 $R_{0}=1 \mu \mathrm{m}$ の気泡では表面張力が $2 S_{H_{g}} / R_{0} \simeq 1 \mathrm{MPa}$ のオーダになる. したがって, 初期ボイド率が同じで も $R_{0}=0.3 \sim 1 \mu \mathrm{m}$ と非常に小さい気泡では初期の気 泡内部気体の圧力（密度）が高く, 体積変化に伴う圧 力変化が大きいために, 最大圧力の上昇が生じると考 えられる. 逆に, $\alpha_{0}=0.05 \sim 0.1 \%$ に対する最大圧力

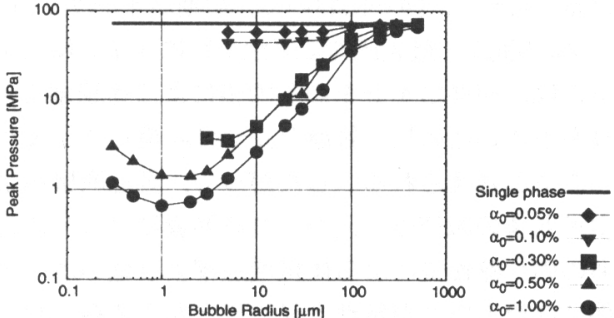

Fig. 6 Peak pressure at the center of cylinder as a function of initial bubble radius for various void fraction $(t=0 \sim 4 \mu s)$

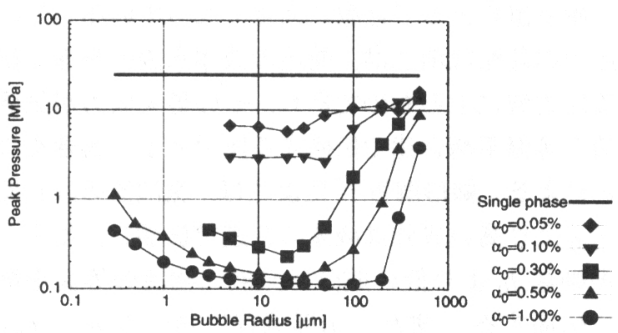

Fig. 7 Peak pressure at the wall of cylinder as a function of initial bubble radius for various void fraction $(t=0 \sim 1000,0 \sim 2000 \mu s)$

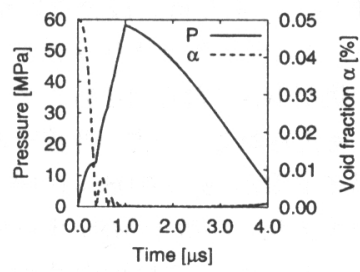

Fig. 8 Collapse of bubble and linear increase of pressure due to the thermal expansion of liquid metals ; time evolution of the pressure at the center of cylinder $\left(\alpha_{0}=0.05 \%, R_{0}=10 \mu \mathrm{m}\right)$

は気泡半径によらず数十 $M P a$ オーダである. 図 8 に ボイド率 $\alpha_{0}=0.05 \%$, 気泡半径 $R_{0}=10 \mu \mathrm{m}$ の条件で の円筒中心の圧力とボイド率の時間変化を示す. 気泡 の崩壊が生じてボイド率が非常に小さくなり，その結 果, 圧力が図 2(a) の単相の場合の結果のように直線的 に増加している. 今, 熱膨張率を $\beta_{L}$, 定圧比熱を $C_{p L}$ および発熱時間を $\Delta \tau$ として，熱膨張による液体金属 の体積増加率 $\Delta f_{L}$ が次のように表される.

$$
\Delta f_{L}=\frac{\beta_{L} Q}{\rho_{L} C_{p L}} \Delta \tau
$$

これから， $\beta_{L}=182 \times 10^{-6} \mathrm{~K}^{-1}, \rho_{L}=13579 \mathrm{~kg} / \mathrm{m}^{3}$ ， $C_{p L}=139 \mathrm{~J} / \mathrm{kg} . \mathrm{K}, Q=26.7 \times 10^{12} \mathrm{~W} / \mathrm{m}^{3}, \Delta \tau=1 \mu \mathrm{s}$ よ り, 熱膨張による体積増加率が $\Delta f_{L}=0.26 \%$ と見積も 
られる.よって, 図6において, 初期ボイド率が $0.1 \%$ 之 $0.3 \%$ の間で, 最大圧力の気泡半径に対する傾向が変 わるのは, 初期ボイド率が熱膨張による体積增加 $\Delta f_{L}$ よりも小さいために, 気泡が完全に収縮してしまうた めであると考えられる. したがって, 気泡崩壊が生じ るボイド率の閜値は, 入力される熱量によって変化す るものの, 熱膨張による体積増加率より低いボイド率 条件では最大圧力が気泡半径にほとんど依存しないと いうことになる.

図 7 の $\alpha_{0}=0.3 \sim 1 \%$ の結果を見れば, 気泡半径が 大きくなるに連れて壁面の最大圧力が狳々に小さくな り, 極小值をとって急激に大きくなっている. この最 大圧力の急激な増加は, 前述の液体水銀の音速で伝播 する圧力波によるものであり, その最大圧力が気液二 相流の等温平衡音速で伝播する圧力波より大きくなる ことによる. 線形解析 ${ }^{(10)}$ によれば, 気泡流の固有振動 数 $f_{m 0}$ より高い成分は液体の音速で伝播し, 気泡の固 有振動数 $f_{0}$ より低い成分は気液二相流の等温平衡音 速で伝播する. また, 伝播過程において $f_{0} \sim f_{m 0}$ 間 の成分に対する減衰が大きいのに比べて, それ以外の 領域における圧力波の隇衰は小さい。つまり, 熱入力 (図 4) によって生じた圧力のうち， $f_{0} \sim f_{m 0}$ の成分は 隇衰してしまい, $f_{0}$ より低い成分だけが等温平衡音 速で伝播する. よって, 気泡半径が大きくなるほど気 泡の固有振動数が小さくなる (図 3) ために最大圧力も 小さくなると考えられる. 一方, 非線形振動する条件 となる初期ボイド率が $\alpha_{0}=0.05 \sim 0.1 \%$ の場合には, 中心における最大圧力が数十 $M P a$ オーダであるにも 関わらず, $R_{0}=5 \sim 30 \mu m$ の壁面の最大圧力は数 $M P a$ オーダまで減衰している. 単相における最大圧力の減 少割合は円筒座標系における波の放射によるが，それ に比べてもより小さくなっており, 低ボイド率であっ ても気泡混入が圧力波の減衰に貢献していることがわ かる.この理由については次節で述べる.

4.4 内部気体の遗いによる影響熱膨張に伴う 圧力上昇の緩和および圧力波の伝播過程における減衰 に対する気泡内部気体の影響を調べるため, 気泡内部 気体にヘリウムを用いた場合, アルゴンの場合および 断熱ポリトロープ変化を仮定した場合を比較して図 9 および図 10 に示す．ただし，アルゴンはへリウムと 比熱が同じで, 熱伝導率が約 10 倍小さいという特徵 がある.

図9より,ヘリウムとアルゴンの結果は, 比熱が同じ であるためにほとんど一致していることがわかる。 そ れに対して, 断熱変化を仮定した場合の中心部の最大 圧力が, ボイド率 $\alpha_{0}=1.0 \%$, 初期気泡半径 $R_{0}=5 \mu \mathrm{m}$

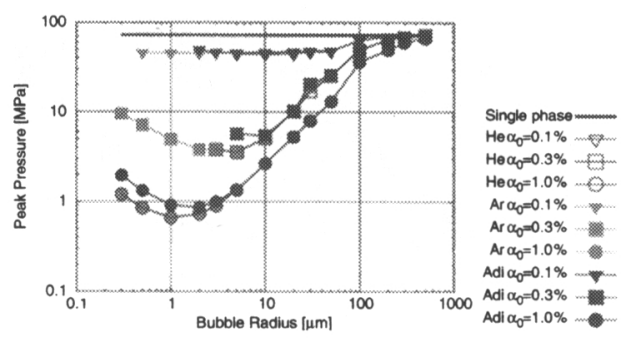

Fig. 9 Comparison of gas speices inside bubble : Peak pressure at the center of cylinder as a function of initial bubble radius for various void fraction $(t=0 \sim 4 \mu s)$

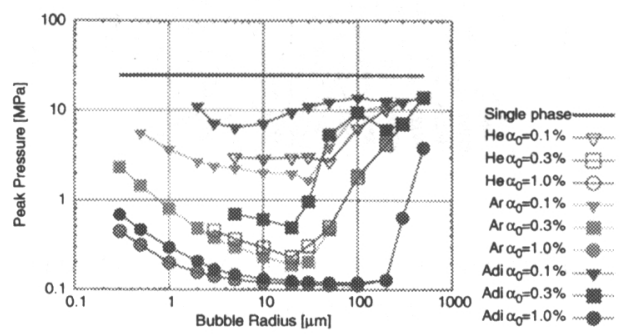

Fig. 10 Comparison of gas speices inside bubble : Peak pressure at the wall of cylinder as a function of initial bubble radius for various void fraction $(t=0 \sim 1000,0 \sim 2000 \mu s)$

以下の気泡において, 他の場合のものに比べて大きな 値となっている.これは, 気泡の収縮に伴う内部気体 の圧縮で生じた熱が周囲流体に散逸されないためであ る. 線形解析 ${ }^{(10)}$ によれば, 気泡内部気体が気泡の固有 周波数 $f_{0}$ より低い周波数では等温的に, 高い周波数 では断熱的に振舞うとされている.よって, 気泡半径 が小さくなるに連れて $f_{0}$ が高くなるために等温的に 振舞うようになり，断熱を仮定した場合とへリウムお よびアルゴンの場合に差が生じる.

一方, 図 10 より, 圧力波の伝播に伴う減衰について は, 各々の結果に対して低ボイド率条件で大きな違いが ある. まず, ヘリウムとアルゴンの結果を比較すると, 初期ボイド率が小さくなるに連れてその差が大きくな ること, また, $\alpha_{0}=0.1 \%$ においては $R_{0}=30 \sim 50 \mu m$ でヘリウムとアルゴンの最大圧力が逆転しており, 気 泡振動における熱隇衰が熱伝導率のみでは決まらな いことがわかる. 断熱変化の結果は, 低ボイド率条件 $\alpha_{0}=0.1 \%$ においてヘリウムやアルゴンの結果に比べ て壁面における最大圧力が大きな値をとっている. 図 9 を見ればこのボイド率では, 中心部で気泡が完全に 収縮してしまう場合であり,このために熱散逸による 減衰の影響がヘリウムとアルゴンの結果にもつとも顕 著に現れたと考えられる. また, $R_{0}=200 \mu \mathrm{m}$ 以上の 


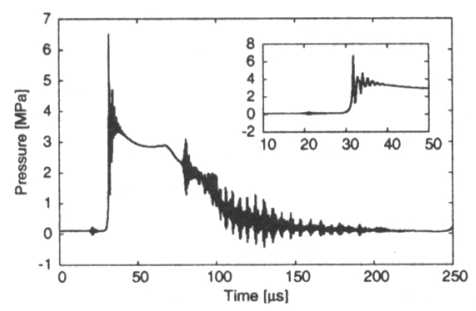

Fig. 11 Time evolution of the pressure at the wall of cylinder $\left(R_{0}=10 \mu m, \alpha_{0}=0.05 \%\right)$

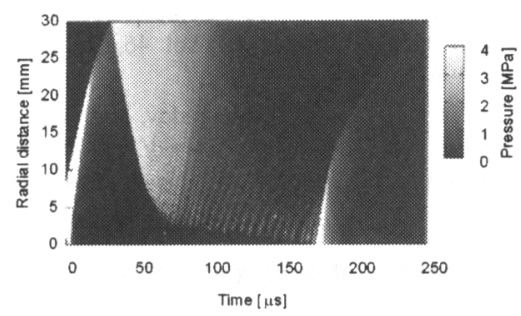

Fig. 12 Time evolution of the pressure distribution $\left(R_{0}=10 \mu m, \alpha_{0}=0.05 \%\right)$

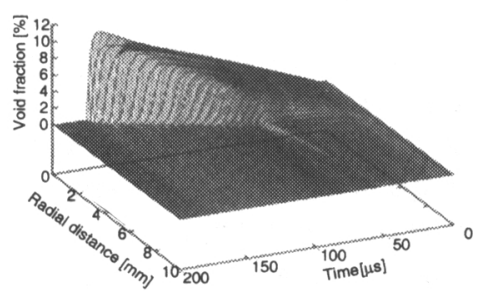

Fig. 13 The growth and collapse of bubble cloud; time evolution of the void fraction near the center of cylinder $\left(R_{0}=10 \mu m, \alpha_{0}=0.05 \%\right)$

気泡半径において, 気泡内部気体の影響が見られない のは, 気泡の体積運動に関係しない前述の液体水銀の 音速で伝播する圧力波のためである.

以上より, 気泡内部気体の熱伝導率の違いは, 熱膨 張に伴う圧力上昇の緩和にほとんど影響しないが, 圧 力波の伝播過程における気泡収縮による熱減衰に大き く影響する. さらに, $R_{0}=30 \mu \mathrm{m}$ 以下の気泡について はへリウムに比べて小さい熱伝導率をもつアルゴンの 方が圧力波の減衰効果がわずかに優位であること, ま た, 断熱変化を仮定した結果との比較から気泡が大き く収縮する低ポイド率条件で熱減衰の効果が大きいこ とがわかる.

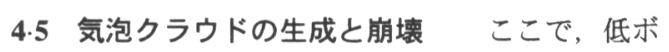
イド率条件（ヘリウム， $\alpha=0.05 \%, R=10 \mu m$ ) にお ける圧力波の伝播過程に注目する. 壁面圧力および圧 力分布の時間変化を図 11 および図 12 に, 中心部近傍
のボイド率分布の時間変化を図 13 に示す．図 12 より, $t=0 \sim 50 \mu \mathrm{s}$ で圧力波が伝播過程において非線形性の ために衝撃波を形成し, 壁面に到達しているのがわか る. また, 図 11 より, この衝撃波の波頭における圧力 変動をみると気泡の体積運動による緩和振動が見られ る.この間, 図 13 より, 中心部近傍で気泡の成長に よりボイド率が $10 \%$ 近くまで上昇し, 気泡クラウド が形成されている. そして, 壁面からの反射波がこの 気泡クラウドに到達し, 気泡クラウドの外から中心に 向かって気泡が崩壊していき, その気泡崩壊による圧 力波が壁面に向かって伝播している様子が図 11 およ び図 12 からわかる. 最終的に, この気泡クラウドが 崩壊するときに, 中心部で高圧力が生じているが, 熱 入力による圧力波に比べて大きな値になっていない. この理由として, 気泡クラウド内部のボイド率が高い ためにクラウド内部を伝播する圧力波の速度が遅いこ と, そして, その間に円筒という閉じた系でクラウド 周囲の圧力が回復してしまっていることが考えられる.

\section{結言}

気泡を含む液体金属中において熱衝撃によって生じ る圧力波の伝播現象を数值的に再現し, 気泡の混入に よる熱膨張に伴う圧力上昇の緩和と圧力波の伝播過程 における減衰に関して以下のような知見を得た.

熱膨張による圧力上昇に対しては, 気泡半径が小さ く, 熱膨張による体積増加率よりもボイド率が高い場 合に気泡収縮による緩和効果が大きい。 また, 緩和効 果は気泡流の固有周波数 $f_{m 0}$ 之熱入力の周波数特性の 関係に大いに依存している.

伝播過程における圧力波の減衰に対しては, 大きい 気泡ほど固有周波数 $f_{0}$ が低いために減衰効果が大き い. しかし, 熱入力に比べて気泡流の固有周波数 $f_{m 0}$ が低い場合, 気泡流中を気液二相流の等温平衡音速で はなく液体水銀の音速で伝播する圧力波が観察され， そのような波が大きくなる場合には隇衰効果が得られ ない.

気泡内部気体の影響を調べた結果, 圧力上昇の緩和 に対してはほとんど差が見られないが, 圧力波の減衰 に対しては, ボイド率が低いほど気泡収縮が激しくな るために熱散逸による減衰効果が顕著になる. また, 気泡クラウドの生成と崩壊が観察されるような低ボイ ド率条件においても, 圧力波の伝播過程に対して気泡 収縮の熱散逸による減衰効果がある.

\section{謝辞}

本研究を進めるに際して, 東京農工大学の亀田正 治氏には貴重な助言を頂きました。また, 著者の一人 
(K.O.) は, 文部科学省 21 世紀 COE プログラム「機械 システム・イノベーション」による補助を受けました. ここに記して謝意を表します。

\section{文献}

(1) Japan Proton Accelerator Research Complex. http://jparc.jp.

(2) Spallation Neutron Source. http://www.sns.gov/.

(3) M. Futakawa, T. Nace, C. C. Tsai, H. Kogawa, S. Ishikura, Y. Ikeda, H. Soyama, and H. Date. Cavitation erosion in mercury target of spallation neutron source. In Proceedings of Fifth International Symposium on Cavitation, Osaka, 1-4 November (CD-ROM), (2003).

(4) Engineering of Bubble : Concepts in Basic Bubble and Foam Engineering. Technosystem, (2005). (in Japanese).

(5) G. Hansen, M. Butzek, H. Glückler, R. Hanslik, H.Soltner, V.Soukhanov, H.Stelzer, and J. Wolters. Engineering Work for the ESS Target Station. In Proceedings of the Sixth International Topical Meeting on Nuclear Applications of Accelerator Technology, San Diego, 1-5, June, (2003).

(6) E. L. Carstensen and L. L. Foldy. Propagation of Sound Through a Liquid Containging Bubbles. J. Acoust. Soc. Am., Vol. 19, No. 3, pp. 481-501, (1947).

(7) L. van Wijngaarden. One-dimensional flow of liquids containing small gas bubbles. Ann. Rev. Fluid Mech., Vol. 4, pp. 369-396, (1972).

(8) R. E. Caflisch, M. J. Miksis, G. C. Papanicolaou, and L Ting. Effective equations for wave propagation in bubbly liquids. J. Fluid Mech., Vol. 153, pp. 259-273, (1985).

(9) J. Rubinstein. Bubble interaction effects on waves in bubbly liquids. J. Acoust. Soc. Am., Vol. 77, No. 6, pp. 2061-2066, (1985).

(10) K. W. Commander and A. Prosperetti. Linear pressure waves in bubbly liquids: Comparison between theory and experiments. J. Acoust. Soc. Am., Vol. 85, No. 2, pp. 732746, (1989).

(11) R. I. Nigmatulin. Dynamics of Multiphase Media Volume 2. Hemisphere, (1991).

(12) M. Kameda and Y. Matsumoto. Shock waves in a liquid containing small gas bubbles. Phys. Fluids, Vol. 8, No. 2, pp. 322-335, (1996).

(13) M. Kameda, N. Shimaura, F. Higashino, and Y. Matsumoto. Shock waves in a uniform bubbly flow. Phys. Fluids, Vol. 10, No. 10, pp. 2661-2668, (1998).

(14) Japan Society of Fluid Mechanics, editor. Fluid Dynamics Series 2 : Dynamics of Multiphase Flow. Asakura Syoten, (1991). (in Japanese).

(15) J. B. Keller and I. I. Kolodner. Damping of Underwater Explosion Bubble Oscillations. J. Appl. Phys., Vol. 27, No. 10, pp. 1152-1161, (1956).

(16) A. Prosperetti and A. Lezzi. Bubble dynamics in a compressible liquid. part 1. first-order theory. J. Fluid Mech., Vol. 168, pp. 457-478, (1986).

(17) T. Kajishima. Numerical Simulation of Turbulent Flows. Yokendo, (1999). (in Japanese).
(18) K. Okita, S. Takagi, and Y. Matsumoto. Numerical analysis for bubbly flows through a convergent-divergent nozzle. In Proceedings of 3rd International Symposium on Two-Phase Flow Modelling and Experimentation, Pisa, 22-24 September (CD-ROM), (2004).

(19) D. R. Lide and H. V. Kehiaian. CRC HANDBOOK of THERMOPHYSICAL and THERMOCHEMICAL DATA. CRC Press, Boca Raton, (1994).

(20) A. R. Hansen and C. A. Eckert. Volumetric Measurements for Some Liquid Metals at High Pressuers and Temperatures. J. Chem. Eng. Data, Vol. 36, pp. 252-255, (1991).

(21) L. A. Davis and R. B. Gordon. Compression of Mercury at High Pressure. J. Chem. Phys., Vol. 46, No. 7, pp. 2650 2660, (1967).

(22) N. B. Vargaftik, Y. K. Vinogradov, and V. S. Yargin Handbook of Physical Properties of Liquids and Gases : Pure Substances and Mixtures. begell house, New York, (1996).

\section{付録 $\mathbf{A}$ 液体水銀の状態方程式}

Hansen \& Eckert ${ }^{(20)}$ によって次式のような液体水銀 の状態方程式が提案されている.

$$
V(T, P) \equiv V\left(T, P_{0}\right)\left[1-C(T) \ln \left(\frac{B(T)+P}{B(T)+P_{0}}\right)\right],
$$

ここで, $V\left(T, P_{0}\right), B(T)$ および $C(T)$ はそれぞれ， $V\left(T, P_{0}\right) \equiv a+b T, B(T) \equiv B_{0}+B_{1} T$ および $C(T) \equiv$ $C_{0}+C_{1} T$ のように定義される. Hansen \& Eckert は体 積と温度の関係から各パラメータを決定しているが,

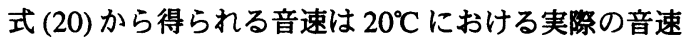
$1450 \mathrm{~m} / \mathrm{s}$ に比べておよそ $10 \%$ 小さい. よって, 本研究 では V-T の関係だけでなく等温圧縮率 ${ }^{(21)}$ を満たすよ うに各パラメータを再フィッティングした. 以下に得 られたパラメータを用いることで, 音速が改善された. $P_{0}=1 \times 10^{-3}[\mathrm{kbar}]$,

$a=14.75\left[\mathrm{~cm}^{3} / \mathrm{mol}\right], \quad b=2.728 \times 10^{-3}\left[\mathrm{~cm}^{3} / \mathrm{mol}^{\circ}{ }^{\circ} \mathrm{C}\right]$ $B_{0}=26.46[\mathrm{kbar}], \quad B_{1}=-2.006 \times 10^{-2}\left[\mathrm{kbar} /{ }^{\circ} \mathrm{C}\right]$ $C_{0}=0.1044 \times 10^{-2}[-], \quad C_{1}=1.348 \times 10^{-5}\left[{ }^{\circ} \mathrm{C}^{-1}\right]$

\section{付䩮 B 気体の熟伝算重}

\section{気体の熱伝導率を温度の関数として表現するために} Sutherlandの式を用いた.

$$
\lambda(T)=\lambda_{\text {ref }}\left(\frac{T}{T_{\text {ref }}}\right)^{n} \frac{T_{\text {ref }}+T_{s}}{T+T_{s}}
$$

各パラメータには，実測值 ${ }^{(22) を も と に し た フ ィ ッ テ ィ ~}$ ングより次のものを用いた.

Helium:

$$
\lambda_{\text {ref }}=156 \times 10^{-3}, \quad T_{\text {ref }}=300, \quad n=1.7, \quad T_{s}=0
$$

Argon:

$\lambda_{\text {ref }}=17.8 \times 10^{-3}, \quad T_{\text {ref }}=300, \quad n=1.645, \quad T_{s}=51.9$ 